\title{
Precision Nitrogen Management Using Chlorophyll Meter for Improving Growth, Productivity and N Use Efficiency of Rice in Subtropical Climate
}

\author{
Mainak Ghosh ${ }^{1,2}$, Dillip Kumar Swain ${ }^{1}$, Madan Kumar Jha ${ }^{1} \&$ Virendra Kumar Tewari ${ }^{1}$ \\ ${ }^{1}$ Agricultural and Food Engineering Department, Indian Institute of Technology, Kharagpur, West Bengal, India \\ ${ }^{2}$ Department of Agronomy, Bihar Agricultural University, Sabour, Bihar, India \\ Correspondence: Dillip Kumar Swain, Agricultural and Food Engineering Department, Indian Institute of \\ Technology Kharagpur, West Bengal, India. Tel: 91-322-228-3170. E-mail: swain@agfe.iitkgp.ernet.in
}

Received: November 6, 2012 Accepted: November 27, 2012 Online Published: January 18, 2013

doi:10.5539/jas.v5n2p253

URL: http://dx.doi.org/10.5539/jas.v5n2p253

\begin{abstract}
$\mathrm{N}$ management must be based on crop demand and supply capacity of the soil. A field experiment was conducted to analyze the effect of chlorophyll meter (SPAD meter) based $\mathrm{N}$ management on growth, productivity and agronomic N use efficiency of rice (cv. IR 36) in lateritic soil of India during the wet season of 2010 and 2011. The Experiment contained twelve $\mathrm{N}$ management treatments such as farmers' fertilizer practice, one fixed time $\mathrm{N}$ management (FTNM), nine treatments of real time N management (RTNM), and one control. The RTNM is the combination of three SPAD threshold (SPAD: 34, 36 and 38) and three N levels (15, 25 and $35 \mathrm{~kg} \mathrm{ha}^{-1}$ ) for top dressing when the SPAD value of rice leaf falls below the threshold. The grain yield of RTNM was in the range 93 to $105 \%$ as that of FTNM, but with lower N application rate. Among RTNM treatments, SPAD 36 with 35 and $25 \mathrm{~kg} \mathrm{~N}$ ha $^{-1}$ top-dressing could save $\mathrm{N}$ fertilizer by 20 to $35 \%$ compared to FTNM without reducing grain yield. Agronomic $\mathrm{N}$ use efficiency can be increased at high yield level using SPAD meter based N management.
\end{abstract}

Keywords: $\mathrm{N}$ management, chlorophyll meter (SPAD), growth; productivity, $\mathrm{N}$ use efficiency

\section{Introduction}

Rice is a staple food crop in the world, cultivated on about 146 million ha with a production of 520 million tons of grains. In India, rice is cultivated on 42.2 million ha with a production of 110.9 million tons, while China produces 187.45 million tons of rice from 33.1 million ha. The productivity of rice in India and China is 2.69 and $5.73 \mathrm{t} \mathrm{ha}^{-1}$, respectively. The increase in rice productivity of China is mainly due to cultivation of hybrid rice under controlled management of water and nutrients (Virmani, 1996). Nitrogen limits the growth of rice in many production systems (Tirol-Padre et al., 1996) and $\mathrm{N}$ management is the most serious nutritional challenges in rice production which helps in carbohydrate accumulation in culm, leaf sheath and grain of rice. Farmers are routinely applying more $\mathrm{N}$ fertilizer than a crop can use is due to the common perception that the general fertilizer recommendations are not appropriate for their location and/or climatic conditions. Flooded soils have several pathways for $\mathrm{N}$ loss resulting in low $\mathrm{N}$ recovery, which creates a problem in rice production system. A blanket recommended $\mathrm{N}$ rate without considering the nutrient supply capacity of the soil and crop need often does not increase the crop productivity. On the other hand, it results in lower $\mathrm{N}$ use efficiency and may cause the deterioration of soil health (Dobermann \& White, 1998).

Thus fertilizer $\mathrm{N}$ recommendations must be based on the crop demand and supply capacity of the soil. Therefore, the difference between the nitrogen supply from the soil and crop need must be mitigated to increase the crop productivity as well as to maintain soil health. Crop growth indicates the $\mathrm{N}$ supply from all sources and $\mathrm{N}$ status of the crop at any given time is a good indicator of $\mathrm{N}$ availability. The chlorophyll content in leaves can indirectly measure the $\mathrm{N}$ status of the crop and thus helps in-season fertilizer $\mathrm{N}$ topdressing in accordance with need of the crop (Peng et al., 1996). Minolta Camera Company developed a portable chlorophyll meter or SPAD (Soil-Plant Analyses Development) meter which can be used to estimate chlorophyll levels in leaves. N is the key element in chlorophyll molecules that capture sunlight used in photosynthesis. Thus chlorophyll meter provides instant crop $\mathrm{N}$ status as SPAD value in a nondestructive manner. 
RTNM is the component of site-specific N management (SSNM) developed by International Rice Research Institute to increase the fertilizer $\mathrm{N}$ use efficiency (Peng et al., 1996; Dobermann et al., 2002; Huang et al., 2008; Gholizadeh et al., 2011) and a certain rate of fertilizer $\mathrm{N}$ has to be applied when leaf $\mathrm{N}$ goes below the critical level in RTNM (Peng et al., 1996). Therefore, time and number of $\mathrm{N}$ applications differs resulting in variation of total $\mathrm{N}$ rates across seasons and locations. Whereas in FTNM, the fertilizer $\mathrm{N}$ is applied in four equal splits at key growth stages (basal, midtillering, panicle initiation and heading). Evaluation of RTNM showed that the same rice yield could be achieved with $20-30 \%$ less use of fertilizer N, but yield increase was rare (Balasubramanian et al., 2000; Hussain et al., 2000; Singh et al., 2002). But in case of FTNM, grain yield increased by $11 \%$ and $\mathrm{N}$ recovery efficiency (REN) by 31 to $40 \%$ as compare to farmers' fertilizer $\mathrm{N}$ management (Dobermann et al., 2002). Use of new technology started in SSNM as it provides good N utilization efficiency so as to make it more effective. Positive relationship was found between chlorophyll and $\mathrm{N}$ content in leaves (Takabe \& Yoneyama, 1989; Peng et al., 1993; Balasubramanian et al., 1999; Singh et al., 2012). Hence, chlorophyll content in leaves can be used as a measure of leaf N status. So, the SPAD meter can synchronize the time of fertilizer $\mathrm{N}$ application in a nondestructive manner with actual crop demand for precision $\mathrm{N}$ management.

Now the challenge is to convert the applied $\mathrm{N}$ in soil to grain with maximum use efficiency as $\mathrm{N}$ is the most critical inputs in rice based cropping system. Generally subtropical belt is located between the tropical and temperate belts and is characterized by periodic alternation of tropical and temperate climatic conditions. In the subtropics, annual rainfall of $1000 \mathrm{~mm}$ provides around $10 \mathrm{~kg} \mathrm{~N} \mathrm{ha}^{-1}$, the soil microbial pool around $5 \mathrm{~kg} \mathrm{~N} \mathrm{ha}^{-1}$, and biological nitrogen fixation around $40 \mathrm{~kg} \mathrm{~N} \mathrm{ha}^{-1}$ per rice crop (Cassman et al., 1998). Mineralization of soil organic matter is rapid in subtropical climate and environmental factors such as temperature and moisture have the strongest impact on the rate of decomposition of organic material. Tropical and subtropical soils often have lower organic matter contents than soils in temperate zones but the rate of decomposition is higher as compared to temperate climate. Thus fertilizer $\mathrm{N}$ use efficiency of cereals remains low in subtropical belt as compared to temperate belt. The present investigation was focused as to how chlorophyll meter help in determining optimal $\mathrm{N}$ management through real time $\mathrm{N}$ application for improving growth, productivity and $\mathrm{N}$ use efficiency of subtropical rice.

\section{Materials and Methods}

\subsection{Field Experiment}

A field experiment was conducted to study the effect of precision nitrogen management based on SPAD values for increasing and stabilizing growth and productivity of rice in red and lateritic soil. The experiment was conducted at the Research Farm of Agricultural and Food Engineering Department, Indian Institute of Technology Kharagpur, Kharagpur ( $22^{\circ} 19^{\prime} \mathrm{N}$ and $87^{\circ} 19^{\prime} \mathrm{E}$ ), India during the wet season (June to November) of 2010 and 2011. The soil of the experimental plot was taxonomically grouped under Haplustaff, sandy loam in texture (65.8\% sand, $20.5 \%$ silt and $12.4 \%$ clay), low in fertility status (196 kg available $\mathrm{N} \mathrm{ha}^{-1}, 14 \mathrm{~kg}$ available $\mathrm{P} \mathrm{ha}^{-1}$ and $96 \mathrm{~kg}$ available $\mathrm{K} \mathrm{ha}^{-1}$ ) and acidic in nature (pH 5.2 and cation exchange capacity $\left.4.1 \mathrm{meq} / 100 \mathrm{~g}\right)$. The climate of Kharagpur is characterized by hot and humid summer (April and May), humid rainy (June to September), moderately hot and dry autumn (October and November), cool and dry winter (December and January) and moderate spring (February and March). The site receives annual rainfall of $1400 \mathrm{~mm}$ of which $70-75 \%$ occurred in the monsoon months (June to October). The average temperature varies from $21^{\circ} \mathrm{C}$ to $32^{\circ} \mathrm{C}$. The crop received low rainfall of $472 \mathrm{~mm}$ during its growing period of 2010. It was a rainfall deficient (33\% below normal) year and the crop experienced dry spell from time to time and had been mitigated by irrigation. But in 2011, the crop received excessive rainfall of $802 \mathrm{~mm}$ (13\% above normal). The occurrence of high rainfall and cloudiness during grain filling affected grain growth of the crop. The maximum temperature ranged from 27.5 to $43.9^{\circ} \mathrm{C}$; while the minimum temperature varied from 22.3 to $28.5^{\circ} \mathrm{C}$ during the cropping season and remained very conducive for growth and productivity of rice.

The experiment was laid out in Completely Randomized Block Design (RCBD) having nine treatment combinations of three SPAD values $\left(34,36\right.$ and 38) and three $\mathrm{N}$ levels $\left(15,25\right.$ and $\left.35 \mathrm{~kg} \mathrm{~N} \mathrm{ha}^{-1}\right)$ at each top dressing under RTNM along with one treatment of FTNM with 120-21.8-50 kg N-P-K ha- ${ }^{-1}$, one farmers' fertilizer practice (FFP) and control (zero-N) with three replications in $6 \mathrm{~m} \mathrm{x} 5 \mathrm{~m}$ plots. All treatment combinations except FFP and control received 30-21.8-50 kg N-P-K ha ${ }^{-1}$ as basal. In the RTNM treatments, N was top dressed in the form of urea when the SPAD value went below the threshold level (Figures 1 and 2). The $\mathrm{N}$ rates of $15,25,35 \mathrm{~kg} \mathrm{ha}^{-1}$ were used for each SPAD thresholds of 34,36 and 38 during both the years. The SPAD meter (SPAD 502) was used for SPAD measurement which was started from 20 days after transplanting (DAT) and was continued up to the first flowering at 10 days interval for all treatments and replications. The 
youngest leaves were taken for SPAD measurement on one side of the leaf lamina. A mean of 10 readings per plot was used for the measured SPAD value.

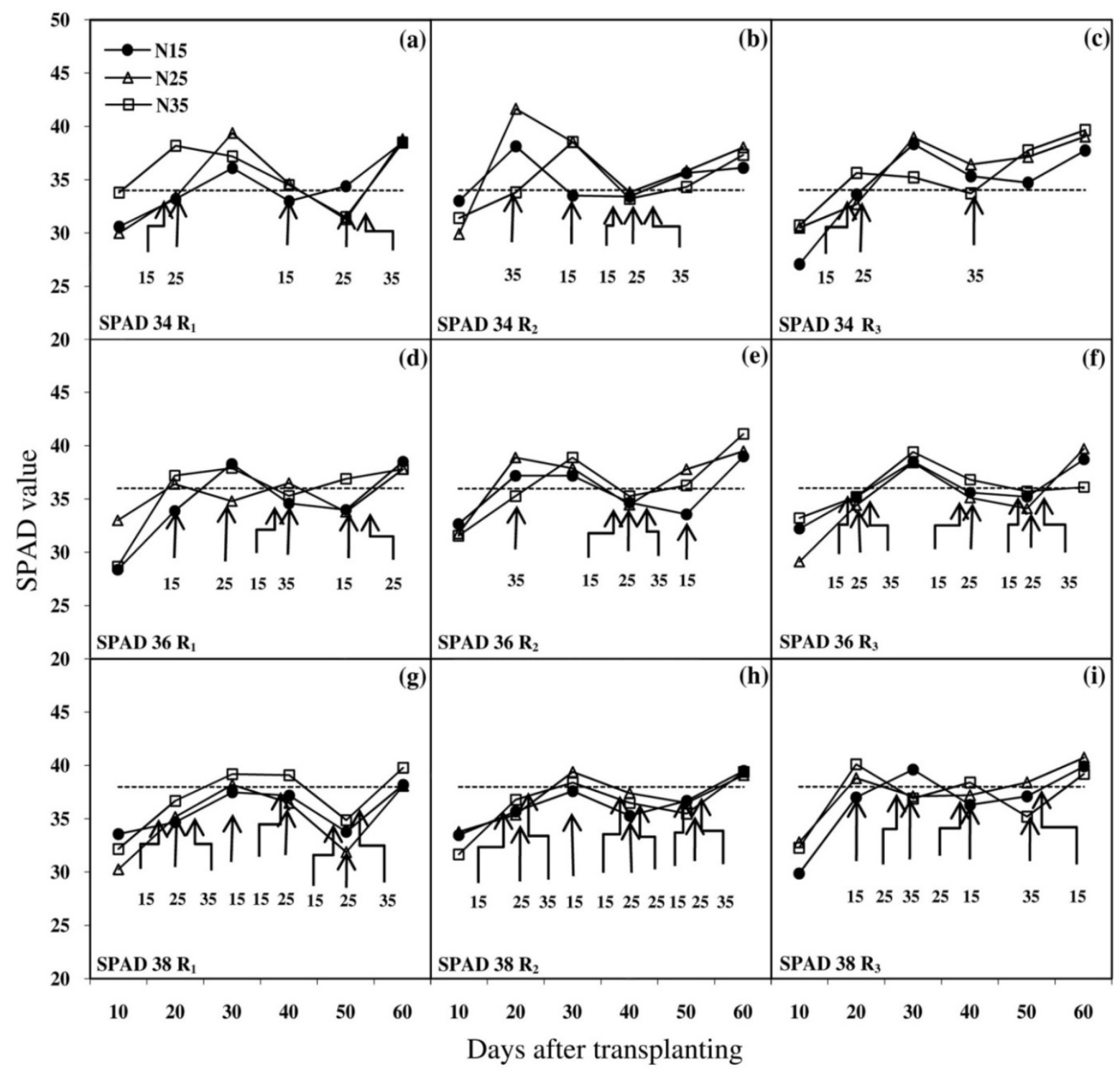

Figure 1. SPAD meter readings at different days after transplanting of rice grown in three $\mathrm{N}$ top dressing $(15,25$ and $35 \mathrm{~kg} \mathrm{~N} \mathrm{ha}^{-1}$ ) with maintenance of three SPAD values with three replications in 2010. Subfigures (a)-(c),

(d)-(f), and (g)-(i) indicate the three replications of SPAD 34, 36, and 38, respectively. Dotted lines are the SPAD thresholds. Lower numbers in each subfigure indicate the rates of $\mathrm{N}$ top dressing in $\mathrm{kg} \mathrm{ha}^{-1}$. Basal $\mathrm{N}$ of $30 \mathrm{~kg}$ $\mathrm{ha}^{-1}$ was applied at 1 day before transplanting. 


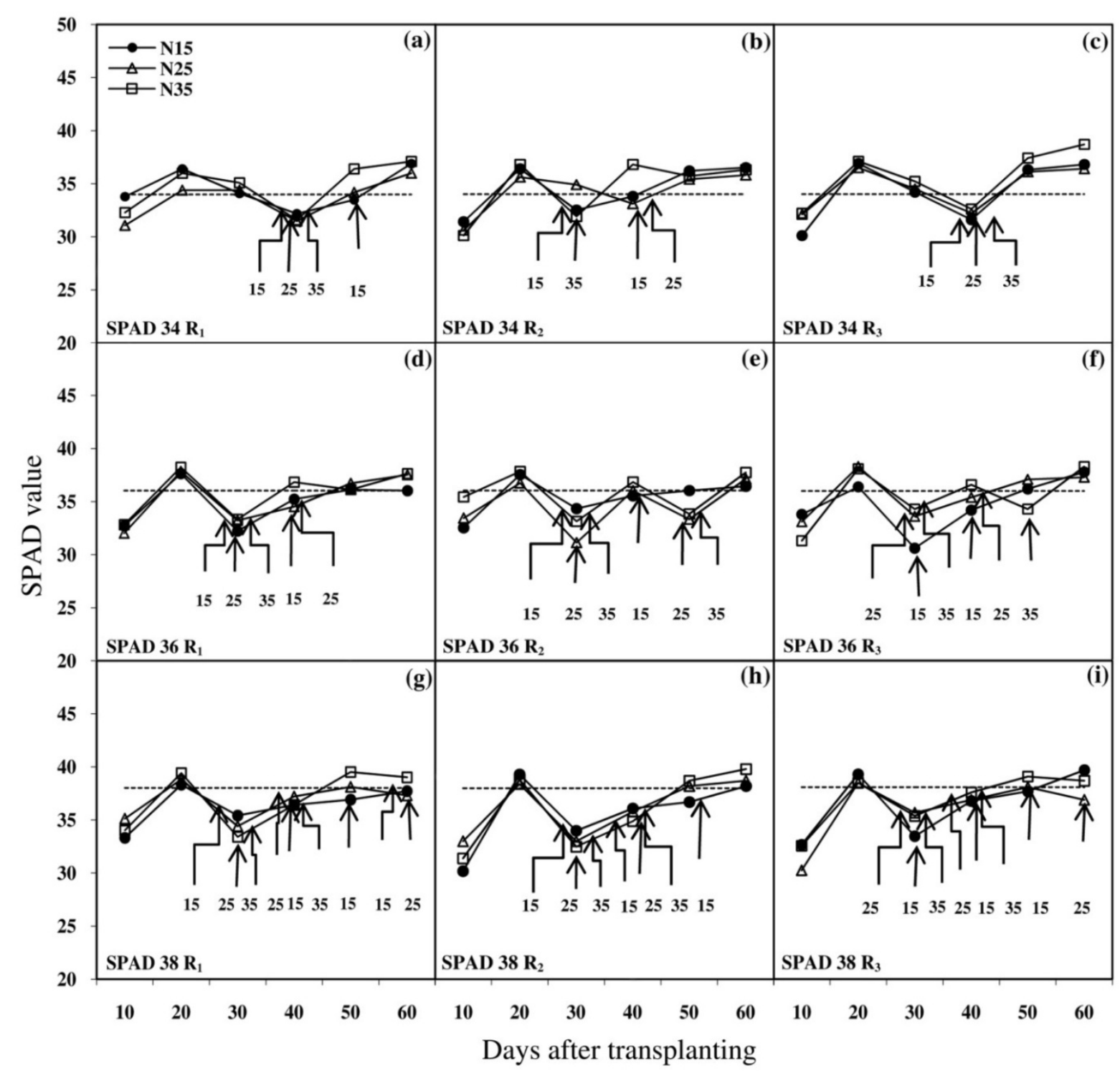

Figure 2. SPAD meter readings at different days after transplanting of rice grown in three $\mathrm{N}$ top dressing $(15,25$ and $35 \mathrm{~kg} \mathrm{~N} \mathrm{ha}^{-1}$ ) with maintenance of three SPAD values with three replications in 2011. Subfigures (a)-(c), (d)-(f),

and (g)-(i) indicate the three replications of SPAD 34, 36, and 38, respectively. Dotted lines are the SPAD thresholds. Lower numbers in each subfigure indicate the rates of $\mathrm{N}$ top dressing in $\mathrm{kg} \mathrm{ha}^{-1}$. Basal $\mathrm{N}$ of $30 \mathrm{~kg}$ $\mathrm{ha}^{-1}$ was applied at 1 day before transplanting.

In the FTNM treatment, $\mathrm{N}$ was top dressed at $30 \mathrm{~kg} \mathrm{ha}^{-1}$ each at mid-tillering, panicle initiation and flowering stage. The FFP treatment received 30-13.1-12.5 kg N-P-K ha ${ }^{-1}$ as basal and same amount of $\mathrm{N}$ and $\mathrm{K}$ at panicle initiation stage as top dressing.

The details of treatment combinations are as follows:

$\begin{array}{llll}\mathrm{T}_{1}=\mathrm{S}_{34} \mathrm{~N}_{15} & \mathrm{~T}_{4}=\mathrm{S}_{36} \mathrm{~N}_{15} & \mathrm{~T}_{7}=\mathrm{S}_{38} \mathrm{~N}_{15} & \mathrm{~T}_{10}=\text { FTNM }\left(120-21.8-50 \mathrm{~kg} \mathrm{~N}-\mathrm{P}-\mathrm{K} \mathrm{ha}{ }^{-1}\right) \\ \mathrm{T}_{2}=\mathrm{S}_{34} \mathrm{~N}_{25} & \mathrm{~T}_{5}=\mathrm{S}_{36} \mathrm{~N}_{25} & \mathrm{~T}_{8}=\mathrm{S}_{38} \mathrm{~N}_{25} & \mathrm{~T}_{11}=\text { FFP }\left(60-13.1-25 \mathrm{~kg} \mathrm{~N}-\mathrm{P}-\mathrm{K} \mathrm{ha}^{-1}\right) \\ \mathrm{T}_{3}=\mathrm{S}_{34} \mathrm{~N}_{35} & \mathrm{~T}_{6}=\mathrm{S}_{36} \mathrm{~N}_{35} & \mathrm{~T}_{9}=\mathrm{S}_{38} \mathrm{~N}_{35} & \mathrm{~T}_{12}=\text { Control (No application of fertilizer) }\end{array}$




\subsection{Variety}

Rice variety 'IR-36' developed at IRRI was used for this investigation. It is a prominent variety in subtropical climate, nearly $50 \%$ of rice farmers used to cultivate this variety in boro (dry) season and $25 \%$ in kharif (wet) season. IR-36 has been recommended as a non coagulating type and can be matured in 115 to 120 days. It is a semi-dwarf variety that proved highly resistant to a number of the major insect pests and diseases that drove down farmers' rice yields and raised prices of the staple food for Asian families.

\subsection{Planting and Intercultural Operation}

Pre-germinated seeds were sown on seedbed and twenty two-day-old seedlings were transplanted on 15 July, 2010 and 16 July, 2011 at a hill spacing of $20 \mathrm{~cm}$ x $20 \mathrm{~cm}$ with 2 seedlings per hill. Basal N, P and K were applied and incorporated in all plots of RTNM, FTNM and FFP treatments before transplanting. Standard cultural practices were followed in crop management. The experimental field remained at saturation from transplanting to 10 days before maturity. The crop was protected from insect-pests incidence by the use of insecticide; but it did not require fungicide application. The weeds were removed manually at 20 and 40 DAT during both the years. Final harvest was done on 15 October, 2010 and 16 October, 2011.

\subsection{Observations Recorded}

The observation on plant height and tiller number, including mother stem, was recorded from 20 hills randomly selected in each plot at different stages and their average was worked out. Plant samples of five hills have been collected at tillering, panicle initiation, heading, 15 days after heading and maturity from each plot. The plant samples were then washed in water to remove mud and dust before separating each sample into stem (stem, leaf sheath and dead leaves), green leaves (lamina) and panicles. The separated plant parts were kept in separate paper packets which in turn placed in an oven for drying at $65-70^{\circ} \mathrm{C}$ till constant weights were obtained. The dry weight of leaves stems and panicles were noted and used for determining crop growth rate (CGR) and leaf area index (LAI). The sum of dry weights of these plant parts were taken as the total dry matter production. The leaf area of ten green leaves was measured with a leaf area meter (AM 300, USA) and put them in hot air oven for drying. The ratio of area/weight of these leaves was used for determining leaf area index (LAI) as suggested by Watson (1952). Panicle number was counted from five hills in each plot at maturity to determine panicle number per $\mathrm{m}^{2}$. The panicles of three hills were hand-threshed and the filled spikelets were separated from unfilled spikelets to count the number of filled and unfilled spikelets per panicle at maturity. The filled spikelets were then oven-dried at $65-70^{\circ} \mathrm{C}$ till constant weights were obtained for determining test weight. Grain filling percentage $(100 \times$ number of filled spikelet/total number of spikelet) was recorded. Agronomic-N use efficiency $\left(\mathrm{AE}_{\mathrm{N}}\right)$ was estimated as the increase in grain yield per unit of applied N. Total dry matter production was used for determining crop growth rate (CGR). The CGR during the period of 20-40, 40-60, 60-75 and 75-90 DAT were estimated using the following formula: $C G R=\left(\mathrm{W}_{2}-\mathrm{W}_{1}\right) /\left(\mathrm{t}_{2}-\mathrm{t}_{1}\right)$ expressed in $\mathrm{g} \mathrm{m}^{-2}$ day ${ }^{-1}$ where, $\mathrm{W}_{2}$ and $\mathrm{W}_{1}$ were the final and initial dry weights of all plant parts per unit land area at times $t_{2}$ and $t_{1}$ respectively (Watson, 1952). Observations on grain yield, straw yield and harvest index were recorded at maturity. The crop was harvested from 5 square meter area kept for yield estimation in each plot. After threshing the grain and straw were dried in the sun for 3-4 days and their weights were recorded. The grain and straw yields were converted into $\mathrm{tha}^{-1}$ and corrected to $12 \%$ moisture content.

\subsection{Statistical Analysis}

Year wise data were analyzed statistically by statistical software Mstat-C, version 1.41 using analysis of variance and treatments were compared with least significant difference (LSD) at the $\mathrm{P}=0.05$ level of significance for both the year.

\section{Results and Discussion}

\subsection{Growth Attributes}

Number of tillers $\mathrm{m}^{-2}$ showed increasing tendency receiving higher dose of $\mathrm{N}$ top dressing $\left(25\right.$ or $\left.35 \mathrm{~kg} \mathrm{~N}^{-1}\right)$ at higher SPAD $\left(\mathrm{S}_{36}\right.$ and $\left.\mathrm{S}_{38}\right)$ values over those obtained with low rate of $\mathrm{N}$ top dressing $\left(15 \mathrm{~kg} \mathrm{~N} \mathrm{ha}^{-1}\right)$ at low SPAD $\left(\mathrm{S}_{34}\right)$ value, FFP and control treatments; but was at par with FTNM during both the years (Table 1). The tiller number between the low and moderate $\mathrm{N}$ rates did not vary significantly. The higher rate of $\mathrm{N}$ application at higher SPAD value was conducive for tiller production. This might be due to favorable effect of $\mathrm{N}$ on cell division and tissue organization that ultimately improved tiller formation at tillering stage (Huang et al., 2008). The N management under RTNM and FTNM did not cause much variation in plant height, though $\mathrm{N}$ application varied from 55 to $120 \mathrm{~kg} \mathrm{ha}^{-1}$ under different $\mathrm{N}$ management treatment. All the $\mathrm{N}$ management treatments significantly increased tiller production and plant height over control during both the years. 
Table 1. Tiller number, plant height and leaf area index of rice grown under different nitrogen management in Kharagpur, India

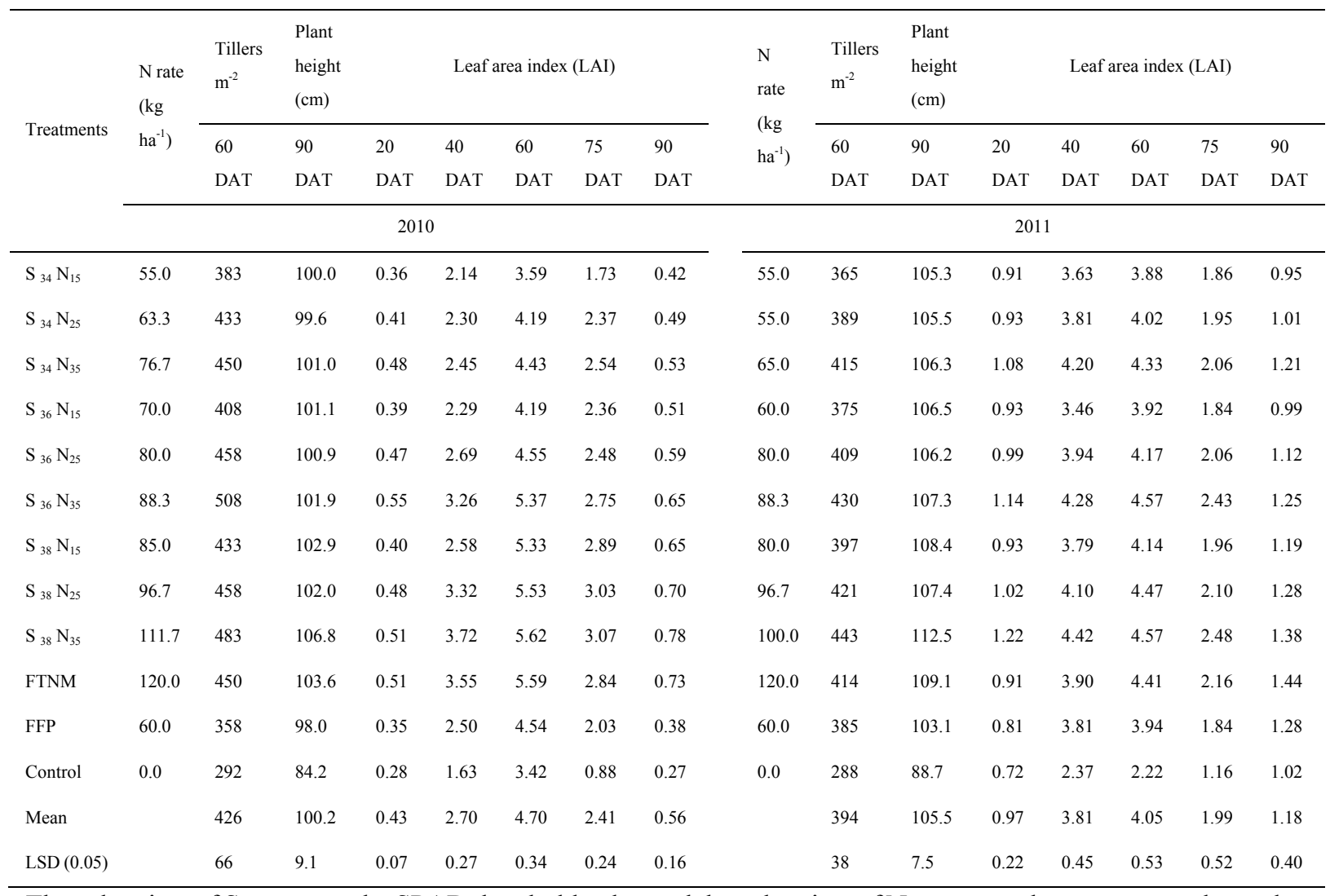

The subscripts of S represent the SPAD threshold value and the subscripts of $\mathrm{N}$ represent the amount top dressed as $\mathrm{kg} \mathrm{N} \mathrm{ha}^{-1}$ in each application; FTNM-Fixed Time Nitrogen Management; FFP - Farmers' Fertilizer Practice.

Leaf area index (LAI) increased steadily from 20 DAT to 60 DAT (flowering). Thereafter, it decreased sharply as the plant progressed towards its maturity during both the years (Table 1). LAI followed a trend similar to that of tiller production. LAI was highly affected by $\mathrm{N}$ rates. It increased steadily due to increasing rate of $\mathrm{N}$ application irrespective of SPAD values during both the years (Table 1). The crop at control plot recorded the lowest LAI values at all the stages under study. Top dressing of $\mathrm{N}$ at low rate $\left(15 \mathrm{~kg} \mathrm{~N}^{\mathrm{a}} \mathrm{a}^{-1}\right.$ when SPAD value falls below the threshold level) under the RTNM recorded significantly lower LAI value as compared to those obtained with higher rate of $\mathrm{N}$ application $\left(25\right.$ or $35 \mathrm{~kg} \mathrm{~N} \mathrm{ha}^{-1}$ ) under all the threshold SPAD levels during both the years. Top dressing of high $\mathrm{N}$ rate $\left(35 \mathrm{~kg} \mathrm{~N} \mathrm{ha}^{-1}\right)$ produced the highest values of LAI while medium $\mathrm{N}$ rate $\left(25 \mathrm{~kg} \mathrm{~N} \mathrm{ha}^{-1}\right)$ produced intermediated LAI values. Both these treatments recorded LAI values at par with FTNM but significantly higher over control treatment at most of the growth stages during both the years. Application of $\mathrm{N}$ under high SPAD $\left(\mathrm{S}_{38}\right)$ values showed a tendency of increasing LAI but not exceeding the values obtained with FTNM. The LAI value at FFP was also quite high and comparable to those obtained with low rate of N application under RTNM. The result showed that N management through RTNM increased LAI comparable to those obtained with FTNM at different growth stages with much lower rate of N application than FTNM. The results indicated that the growth of rice crop could be improved markedly by proper timing of $\mathrm{N}$ application at a much low rate through RTNM using chlorophyll meter.

Relatively higher crop growth rate (CGR) was maintained during the entire growth period of 2010 as compared to that of 2011 (Table 2). The CGR increased up to flowering then decreased gradually as the crop progressed towards its maturity. Accordingly the highest CGR value was recorded during panicle initiation to flowering (40-60 DAT) in both the years. The CGR differed significantly among the $\mathrm{N}$ management treatments under RTNM and increased with increasing $N$ rates at different SPAD values and were comparable to those of FTNM but greater than that of FFP and control plots during both the years. The control plots recoded the lowest CGR value, which was significantly lower than those of all $\mathrm{N}$ management treatments during all the growth periods in both the years. FFP also recorded lower CGR values than those at higher N rate under RTNM and FTNM. The 
high CGR value recorded during grain filling period was responsible for higher grain yield in 2010 as compared to that of 2011.

Table 2. Crop growth rate and total biomass production of rice grown under different nitrogen management in Kharagpur, India

\begin{tabular}{|c|c|c|c|c|c|c|c|c|c|c|c|c|}
\hline \multirow{4}{*}{ Treatments } & \multirow{3}{*}{$\begin{array}{l}\mathrm{N} \\
\text { rate } \\
(\mathrm{kg} \\
\left.\mathrm{ha}^{-1}\right)\end{array}$} & \multicolumn{4}{|c|}{ Crop growth rate $\left(\mathrm{g} \mathrm{m}^{-2}\right.$ day $\left.^{-1}\right)$} & \multirow{3}{*}{$\begin{array}{l}\text { Total } \\
\text { biomass } \\
\left(\mathrm{kg} \mathrm{ha}^{-1}\right)\end{array}$} & \multirow{3}{*}{$\begin{array}{l}\mathrm{N} \\
\text { rate } \\
(\mathrm{kg} \\
\left.\mathrm{ha}^{-1}\right)\end{array}$} & \multicolumn{4}{|c|}{ Crop growth rate $\left(\mathrm{g} \mathrm{m}^{-2}\right.$ day $\left.^{-1}\right)$} & \multirow{3}{*}{$\begin{array}{l}\begin{array}{l}\text { Total } \\
\text { biomass } \\
\left(\mathrm{kg} \mathrm{ha}^{-1}\right)\end{array} \\
90 \text { DAT }\end{array}$} \\
\hline & & \multirow{2}{*}{$\begin{array}{l}20-40 \\
\text { DAT }\end{array}$} & \multirow{2}{*}{$\begin{array}{l}40-60 \\
\text { DAT }\end{array}$} & \multirow{2}{*}{$\begin{array}{l}60-75 \\
\text { DAT }\end{array}$} & \multirow{2}{*}{$\begin{array}{l}75-90 \\
\text { DAT }\end{array}$} & & & \multirow{2}{*}{$\begin{array}{l}20-40 \\
\text { DAT }\end{array}$} & \multirow{2}{*}{$\begin{array}{l}40-60 \\
\text { DAT }\end{array}$} & \multirow{2}{*}{$\begin{array}{l}60-75 \\
\text { DAT }\end{array}$} & \multirow{2}{*}{$\begin{array}{l}75-90 \\
\text { DAT }\end{array}$} & \\
\hline & & & & & & & & & & & & \\
\hline & \multicolumn{6}{|c|}{2010} & \multicolumn{6}{|c|}{2011} \\
\hline $\mathrm{S}_{34} \mathrm{~N}_{15}$ & 55.0 & 13.1 & 19.2 & 14.5 & 11.2 & 10935 & 55.0 & 8.8 & 17.9 & 11.6 & 8.8 & 9024 \\
\hline $\mathrm{S}_{34} \mathrm{~N}_{25}$ & 63.3 & 14.5 & 20.0 & 16.6 & 12.1 & 12079 & 55.0 & 8.8 & 17.8 & 12.2 & 9.0 & 9136 \\
\hline $\mathrm{S}_{34} \mathrm{~N}_{35}$ & 76.7 & 14.4 & 21.0 & 17.6 & 13.2 & 12507 & 65.0 & 9.2 & 18.4 & 13.8 & 9.3 & 9721 \\
\hline $\mathrm{S}_{36} \mathrm{~N}_{15}$ & 70.0 & 12.9 & 21.3 & 18.2 & 13.0 & 12082 & 60.0 & 5.6 & 19.0 & 15.2 & 9.5 & 9220 \\
\hline $\mathrm{S}_{36} \mathrm{~N}_{25}$ & 80.0 & 14.1 & 21.5 & 18.9 & 13.2 & 12613 & 80.0 & 6.5 & 19.5 & 15.3 & 10.1 & 9747 \\
\hline $\mathrm{S}_{36} \mathrm{~N}_{35}$ & 88.3 & 16.8 & 21.8 & 19.4 & 13.1 & 13583 & 88.3 & 7.2 & 19.6 & 15.2 & 10.2 & 10000 \\
\hline $\mathrm{S}_{38} \mathrm{~N}_{15}$ & 85.0 & 14.1 & 21.4 & 19.7 & 12.5 & 12550 & 80.0 & 6.0 & 19.6 & 14.6 & 9.4 & 9394 \\
\hline $\mathrm{S}_{38} \mathrm{~N}_{25}$ & 96.7 & 16.0 & 22.5 & 20.0 & 13.5 & 13521 & 96.7 & 6.6 & 19.5 & 15.5 & 9.8 & 9759 \\
\hline $\mathrm{S}_{38} \mathrm{~N}_{35}$ & 111.7 & 17.2 & 21.9 & 21.1 & 13.9 & 13866 & 100.0 & 7.4 & 19.7 & 14.5 & 10.1 & 10004 \\
\hline FTNM & 120.0 & 16.9 & 21.4 & 20.5 & 12.5 & 13449 & 120.0 & 6.6 & 19.6 & 14.4 & 9.8 & 9544 \\
\hline FFP & 60.0 & 12.0 & 18.1 & 12.9 & 10.3 & 9920 & 60.0 & 9.5 & 17.2 & 10.4 & 7.8 & 8604 \\
\hline Control & 0.0 & 11.1 & 14.1 & 10.1 & 4.7 & 7829 & 0.0 & 4.3 & 14.7 & 7.3 & 4.7 & 6050 \\
\hline Mean & & 14.4 & 20.4 & 17.5 & 11.9 & 12078 & & 7.2 & 18.5 & 13.3 & 9.0 & 9184 \\
\hline $\begin{array}{l}\text { LSD } \\
(0.05)\end{array}$ & & 1.3 & 2.8 & 2.5 & 2.0 & 799 & & 1.2 & 2.2 & 2.0 & 1.5 & 835 \\
\hline
\end{tabular}

The subscripts of S represent the SPAD threshold value and the subscripts of $\mathrm{N}$ represent the amount top dressed as $\mathrm{kg} \mathrm{N} \mathrm{ha}^{-1}$ in each application; FTNM-Fixed Time Nitrogen Management; FFP-Farmers' Fertilizer Practice.

Total dry matter accumulation or total biomass recorded at 90 DAT (maturity) generally increased with total $\mathrm{N}$ rate during both 2010 and 2011 (Table 2). Application of high $\mathrm{N}$ rate $\left(35 \mathrm{~kg} \mathrm{~N}^{-1}\right)$ at high SPAD value produced the highest total dry weight but comparable to that of medium $\mathrm{N}$ rate $\left(25 \mathrm{~kg} \mathrm{~N}^{-1}\right)$ at same SPAD and also of 25 and $35 \mathrm{~kg} \mathrm{~N} \mathrm{ha}^{-1}$ at medium SPAD value of 36 during both the years. FTNM also had higher total dry weight than those obtained with low $\mathrm{N}$ rate under all SPAD values and all $\mathrm{N}$ rates at lower SPAD values in RTNM, but comparable to the other N management treatments in 2010. While in 2011, FTNM recorded total dry weight comparable to all other N management treatments under RTNM; it had higher dry matter production only over FFP and control plots. The crop of the control plots produced the lowest total dry weight which was significantly lower than those of all $\mathrm{N}$ management treatments in both the years. FFP recorded lower total dry weight than those of other N management treatments under RTNM and FTNM, but significantly higher than that of the control plots during both the years. The high biomass production at maturity were mainly due to the high crop growth rate during the ripening phase (flowering to maturity) when medium and high $\mathrm{N}$ rate (25 and $35 \mathrm{~kg}$ $\mathrm{N} \mathrm{ha}^{-1}$ ) at critical SPAD value was applied. 


\subsection{Crop Productivity}

Grain yield responded well to $\mathrm{N}$ application during both the years (Table 3). Grain yield obtained in 2010 was $13.1 \%$ higher than that of 2011. Higher grain yield in 2010 was mainly attributed for higher number of grains per unit area, more panicle density (Table 4) and greater test weight because of better grain filling in clear sunny days during grain filling period as compared to 2011 when the sky overcast with clouds and frequent rainfall affected grain filling resulting in lower number of grains per unit area, lower test weight and ultimately lower grain yield. Gravois and Helms (1992) indicated that genotypes that had high number of grains and panicles per unit area ensured high percentage of fertile spikelets and thus had higher grain yields. The grain yield did not vary significantly among the $\mathrm{N}$ management treatments at same SPAD values under RTNM during both the years. FTNM also recorded high grain yield, which was comparable to other $\mathrm{N}$ management with higher $\mathrm{N}$ rates. Among the RTNM, the SPAD value of 34 and $\mathrm{N}$ rate of $15 \mathrm{~kg} \mathrm{ha}^{-1}$ resulted in a decline in grain yield as compared to the FTNM. However, the other RTNM at higher SPAD of 36 and 38 with N rate of 25 and $35 \mathrm{~kg}$ $\mathrm{ha}^{-1}$ resulted in no change or marginal increase in grain yield as compared to the FTNM (Figure 3). The highest grain yield has been achieved with total $\mathrm{N}$ application of $88 \mathrm{~kg} \mathrm{~N}$ ha $^{-1}$ in 2010 and $100 \mathrm{~kg} \mathrm{~N}^{-1}$ in 2011 under the RTNM, which was comparable to that obtained by applying $120 \mathrm{~kg} \mathrm{~N} \mathrm{ha}^{-1}$ in FTNM during both the years. Applying $35 \mathrm{~kg} \mathrm{~N}^{-1}$ as top dressing on basis of SPAD value resulted in significantly higher yield over the dose of $15 \mathrm{~kg} \mathrm{~N} \mathrm{ha}^{-1}$, but was comparable to that of $25 \mathrm{~kg} \mathrm{~N} \mathrm{ha}^{-1}$. In general, all the RTNM had received a lower N application rate as compared to that of FTNM as blanket recommended dose practiced by rice farmers in subtropical belt (Peng et al., 2006). Our data suggest that excessive use of $\mathrm{N}$ input might have reduced the yield advantage of FTNM over RTNM during both the years. With reference to grain yield, the SPAD 36 and 38 were comparable, but SPAD 36 had lower N requirement as compared to that of SPAD 38. Hence for precision N management aiming at high grain yield with higher $\mathrm{N}$ use efficiency the optimal SPAD threshold was evaluated as 36 for both the years.

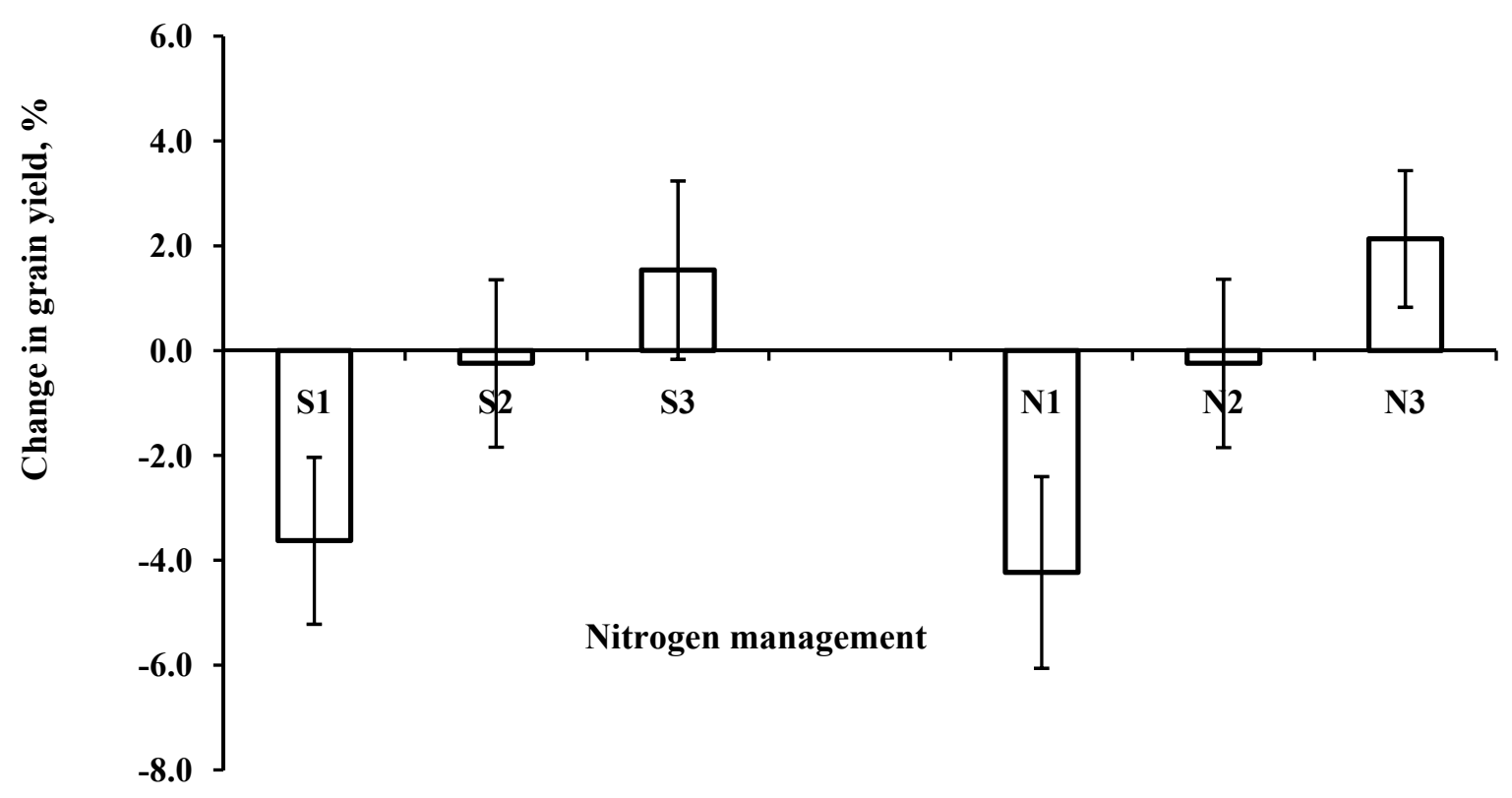

Figure 3. Change in grain yield under SPAD based real time $\mathrm{N}$ management over fixed time $\mathrm{N}$ management (averaged over two years). The vertical lines indicate the standard error

$\mathrm{S}_{1}, \mathrm{~S}_{2}$ and $\mathrm{S}_{3}$ represent $\mathrm{SPAD}$ threshold levels of 34,36 and 38 respectively; $\mathrm{N}_{1}, \mathrm{~N}_{2}$ and $\mathrm{N}_{3}$ represent $\mathrm{N}$ top dressing at 15,25 and $35 \mathrm{~kg} \mathrm{ha}^{-1}$ in respectively. 
Table 3. Yield, harvest index and agronomic $\mathrm{N}$ use efficiency $\left(\mathrm{AE}_{\mathrm{N}}\right)$ of rice grown under different nitrogen management in Kharagpur, India

\begin{tabular}{|c|c|c|c|c|c|c|c|c|c|c|}
\hline Treatments & $\begin{array}{c}\text { N rate } \\
(\mathrm{kg} \\
\left.\mathrm{ha}^{-1}\right)\end{array}$ & $\begin{array}{c}\text { Grain } \\
\text { yield } \\
\left(\mathrm{kg} \mathrm{ha}^{-1}\right)\end{array}$ & $\begin{array}{c}\text { Straw } \\
\text { yield } \\
\left(\mathrm{kg} \mathrm{ha}^{-1}\right)\end{array}$ & $\begin{array}{c}\text { Harvest } \\
\text { index } \\
(\%)\end{array}$ & $\begin{array}{c}\mathrm{AE}_{\mathrm{N}} \\
(\mathrm{kg} \\
\left.\mathrm{kg}^{-1}\right)\end{array}$ & $\begin{array}{c}\mathrm{N} \text { rate } \\
(\mathrm{kg} \\
\left.\mathrm{ha}^{-1}\right)\end{array}$ & $\begin{array}{c}\text { Grain } \\
\text { yield } \\
\left(\mathrm{kg} \mathrm{ha}^{-1}\right)\end{array}$ & $\begin{array}{c}\text { Straw } \\
\text { yield } \\
\left(\mathrm{kg} \mathrm{ha}^{-1}\right)\end{array}$ & $\begin{array}{c}\text { Harvest index } \\
(\%)\end{array}$ & $\begin{array}{c}\mathrm{AE}_{\mathrm{N}} \\
(\mathrm{kg} \\
\left.\mathrm{kg}^{-1}\right)\end{array}$ \\
\hline & \multicolumn{5}{|c|}{2010} & \multicolumn{5}{|c|}{2011} \\
\hline $\mathrm{S}_{34} \mathrm{~N}_{15}$ & 55.0 & 5014 & 5402 & 48.1 & 24.7 & 55.0 & 4645 & 5093 & 47.7 & 18.8 \\
\hline $\mathrm{S}_{34} \mathrm{~N}_{25}$ & 63.3 & 5436 & 6010 & 47.5 & 29.6 & 55.0 & 4694 & 5129 & 47.8 & 19.9 \\
\hline $\mathrm{S}_{34} \mathrm{~N}_{35}$ & 76.7 & 5566 & 6296 & 46.9 & 25.9 & 65.0 & 4803 & 6033 & 44.3 & 18.6 \\
\hline $\mathrm{S}_{36} \mathrm{~N}_{15}$ & 70.0 & 5387 & 6079 & 47.0 & 26.5 & 60.0 & 4686 & 5729 & 45.0 & 18.1 \\
\hline $\mathrm{S}_{36} \mathrm{~N}_{25}$ & 80.0 & 5585 & 6353 & 46.8 & 27.2 & 80.0 & 4845 & 6031 & 44.6 & 15.6 \\
\hline $\mathrm{S}_{36} \mathrm{~N}_{35}$ & 88.3 & 5827 & 7125 & 45.0 & 25.0 & 88.3 & 4924 & 6317 & 43.8 & 15.6 \\
\hline $\mathrm{S}_{38} \mathrm{~N}_{15}$ & 85.0 & 5425 & 6154 & 46.9 & 21.0 & 80.0 & 4799 & 5856 & 45.0 & 14.9 \\
\hline $\mathrm{S}_{38} \mathrm{~N}_{25}$ & 96.7 & 5687 & 6934 & 45.1 & 21.2 & 96.7 & 4992 & 6262 & 44.3 & 15.0 \\
\hline $\mathrm{S}_{38} \mathrm{~N}_{35}$ & 111.7 & 5786 & 7115 & 44.8 & 19.4 & 100.0 & 5088 & 6275 & 44.8 & 14.9 \\
\hline FTNM & 120.0 & 5696 & 6829 & 45.5 & 17.3 & 120.0 & 4761 & 6033 & 44.1 & 9.7 \\
\hline FFP & 60.0 & 4341 & 4633 & 48.4 & 12.0 & 60.0 & 4204 & 5142 & 45.0 & 10.1 \\
\hline Control & 0.0 & 3619 & 3615 & 50.1 & & 0.0 & 3597 & 4117 & 46.6 & \\
\hline Mean & & 5281 & 6046 & 46.9 & 21.0 & & 4670 & 5668 & 45.3 & 14.3 \\
\hline $\operatorname{LSD}(0.05)$ & & 571 & 823 & 4.5 & 13.0 & & 387 & 482 & NS & 5.6 \\
\hline
\end{tabular}

The subscripts of S represent the SPAD threshold value and the subscripts of $\mathrm{N}$ represent the amount top dressed as $\mathrm{kg} \mathrm{N} \mathrm{ha}^{-1}$ in each application; FTNM-Fixed Time Nitrogen Management; FFP-Farmers' Fertilizer Practice

The relationship between grain yield and average SPAD values recorded from 20 DAT to heading at 10 days interval for each treatment also supported that SPAD threshold 36 should be used in determining the timing of N application (Figure 4). The maximum grain yield of $6098 \mathrm{~kg} \mathrm{ha}^{-1}$ was recorded from the average SPAD value of 37 , which supported the SPAD threshold of 36 to be maintained through topdressing of $\mathrm{N}$ at $25 \mathrm{~kg} \mathrm{ha}^{-1}$ for higher grain yield. Increasing the rate and number of $\mathrm{N}$ application at higher SPAD threshold 38 did not enhance the grain yield, on the contrary, it decreased grain yield particularly in 2010. Total amount of $\mathrm{N}$ application varied from 55 to $112 \mathrm{~kg} \mathrm{~N} \mathrm{ha}^{-1}$ in 2010 and 55 to $100 \mathrm{~kg} \mathrm{~N} \mathrm{ha}^{-1}$ in 2011 and it covered well the range of grain yield of irrigated transplanted rice of this region. The control plots produced the lowest grain yield among all other treatments during both the years. FFP produced grain yield significantly lower than other $\mathrm{N}$ management treatments; but considerably higher grain yield than that of control plots. RTNM was found very effective in determining the optimum SPAD value that in turn helped in adjusting the rate and time of $\mathrm{N}$ topdressing according to the need of the crop (Huang et al., 2008). The results showed that timely adequate $\mathrm{N}$ application through RTNM could considerably reduce the N application rate by 27 to $54 \%$ of the existing $\mathrm{N}$ fertilizer recommendation in FTNM without reducing the rice grain yield. This not only reduces the cost of rice cultivation by saving the fertilizer $\mathrm{N}$ but also increases its use efficiency. 


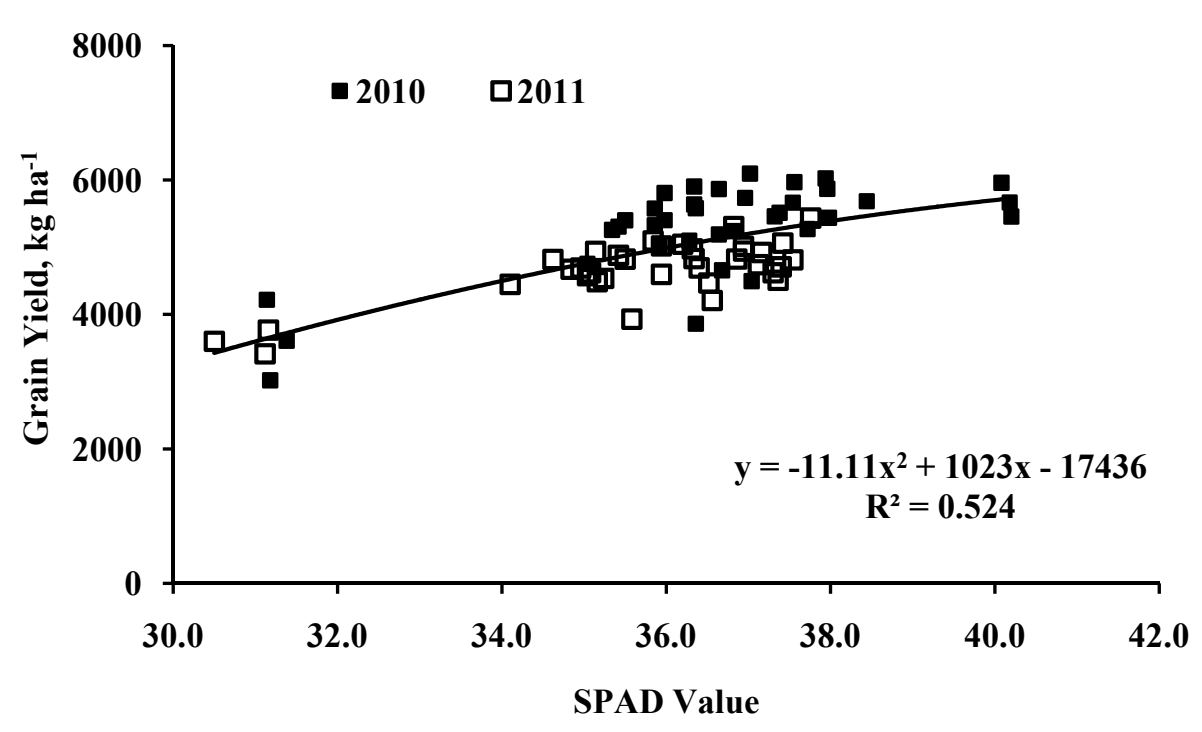

Figure 4. Relationship of rice grain yield $\left(\mathrm{kg} \mathrm{ha}^{-1}\right)$ and SPAD value. The SPAD values were the average readings taken 10 days interval from 20 days after transplanting to heading for each treatment during the years 2010 and 2011

Straw yield showed somewhat different trend from that of the grain yield during both the years (Table 3 ). Straw yield recorded in 2010 was $6.7 \%$ higher than that of 2011 . It increased significantly due to high rate of $\mathrm{N}$ application over low rate at all the SPAD values under RTNM during both the years except at high SPAD value (S38) in 2011. FTNM also produced quite high straw yield comparable to that obtained in different treatments under RTNM during both the years. The result showed greater efficiency of N management through RTNM for improving growth of rice crop as reflected by its straw yield. Almost similar straw yield was obtained by reducing 50\% N through RTNM over FTNM. The maximum straw yield was achieved at SPAD value of 36 with application of $35 \mathrm{~kg} \mathrm{~N} \mathrm{ha}^{-1}$ under RTNM during both the years. Similar higher efficiency of $\mathrm{N}$ management through RTNM in improving growth of rice crop was also noticed by Singh et al. (2002). This indicates that timely adequate $\mathrm{N}$ application through RTNM can considerably reduce the $\mathrm{N}$ rate without reducing straw yield. FFP produced straw yield significantly lower than other $\mathrm{N}$ management treatments except low $\mathrm{N}$ rate at lower SPAD value during both the years, but significantly higher than that of the control plots that produced the lowest straw yield.

Harvest Index (HI) showed a decreasing tendency with increasing $\mathrm{N}$ levels, however, the difference between different treatments was not significant during both the years except control treatment in 2010 (Table 3) which recorded higher $\mathrm{HI}$ as compared to some of the $\mathrm{N}$ management treatments. This might be due to poor vegetative growth of the crop at control plots.

\subsection{Agronomic $N$ Use Efficiency $\left(A E_{N}\right)$}

The $\mathrm{AE}_{\mathrm{N}}$ did not vary significantly among the RTNM treatments during both the years (Table 3 ). However the $\mathrm{AE}_{\mathrm{N}}$ of RTNM was increased by $37 \%$ to $75 \%$ as compared to FTNM (13.5 $\mathrm{kg}$ grain per $\mathrm{kg} \mathrm{N}$ applied) over the years (Figure 5). Among the RTNM, the $\mathrm{AE}_{\mathrm{N}}$ decreased with increasing SPAD value. Whereas, the increasing $\mathrm{N}$ application rate in each top dressing from 15 to $25 \mathrm{~kg} \mathrm{ha}^{-1}$ resulted in increasing $\mathrm{AE}_{\mathrm{N}}$, which later decreased with further increase in $\mathrm{N}$ rate to $35 \mathrm{~kg} \mathrm{ha}^{-1}$. Improved $\mathrm{N}$ supply in SPAD based real time $\mathrm{N}$ management was primarily responsible for increased NUE and high grain yield (Peng et al., 1996). In our study RTNM has increased $\mathrm{AE}_{\mathrm{N}}$ when compared with FTNM because at lower $\mathrm{N}$ rate in RTNM the grain yields were similar or higher than that of FTNM (Huang et al., 2008). In RTNM, application of $25 \mathrm{~kg} \mathrm{~N} \mathrm{ha}^{-1}$ at SPAD 36 increased the $\mathrm{AE}_{\mathrm{N}}$ by $62 \%$ as compared to the FTNM, having similar grain yield. Application of $35 \mathrm{~kg} \mathrm{~N} \mathrm{ha}^{-1}$ at high SPAD value of 38 had lower $\mathrm{AE}_{\mathrm{N}}$ as compared to that of applying $25 \mathrm{~kg} \mathrm{~N}^{-1}$ at $36 \mathrm{SPAD}$, though there was marginal yield increase in the former $\mathrm{N}$ management. The higher $\mathrm{AE}_{\mathrm{N}}$ at $\mathrm{SPAD} 36$ with $25 \mathrm{~kg} \mathrm{~N} \mathrm{ha}^{-1}$ is associated with higher rate of yield increase with lower N application as compared to FTNM. 


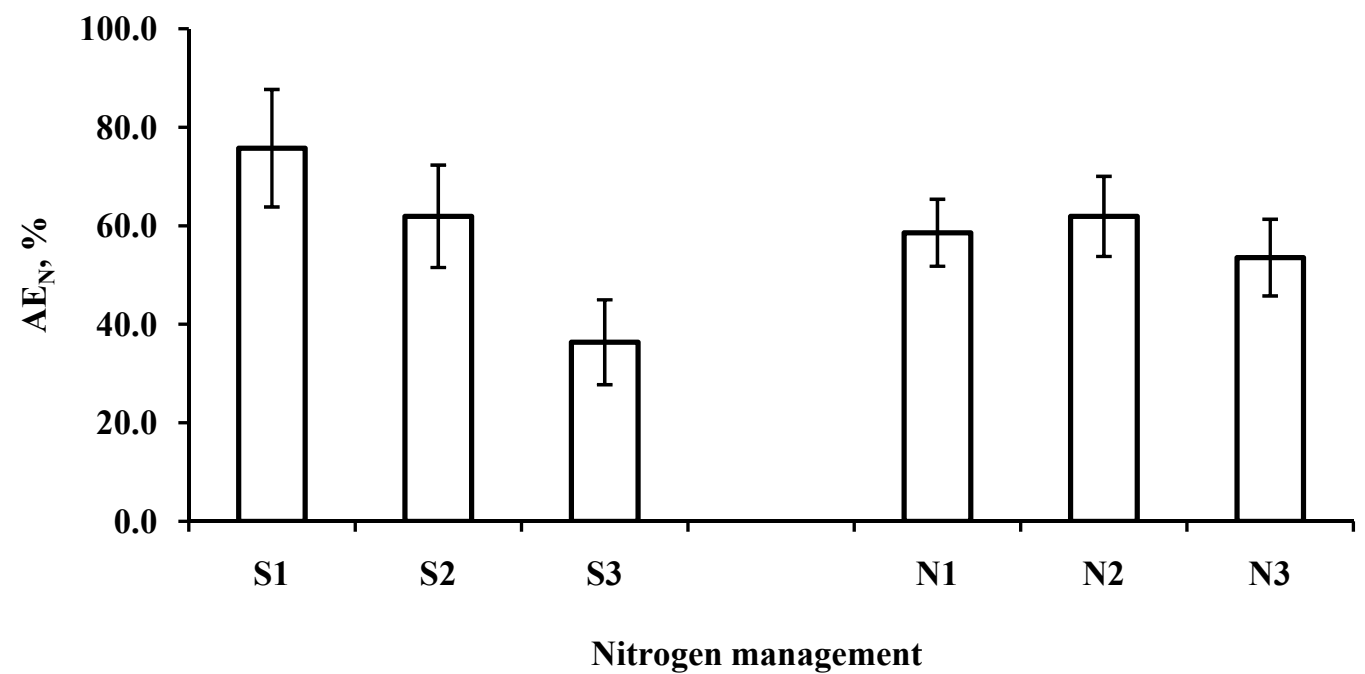

S1, S2 and S3 represent SPAD threshold levels of 34, 36 and 38 respectively; $\mathrm{N} 1, \mathrm{~N} 2$ and $\mathrm{N} 3$ represent $\mathrm{N}$ topdressing at 15,25 and $35 \mathrm{~kg}$ ha-1,in respectively.

Figure 5. Percentage increase in agronomic $\mathrm{N}$ use efficiency (AEN) under SPAD based real time $\mathrm{N}$ management over fixed time $\mathrm{N}$ management (averaged over two years). The vertical lines indicate the standard error

\subsection{Yield Components}

The crop produced $19 \%$ higher number of panicles in 2010 than that of 2011; but, it reduced number of spikelet and grains per panicle by $18 \%$ and $11 \%$ in 2010 as compared to that of 2011 . Flooded condition $(8-10 \mathrm{~cm})$ in the field receiving high rainfall at tillering during 2011 reduced tiller production, hence the panicle number in comparison to that of 2010 (Table 4). The crop received more or less favorable weather condition during panicle formation and spikelet differentiation in both the years as reflected by spikelets production per unit area in which we did not get much variation between the years despite higher number of panicles per unit area in 2010 (Venkateswarlu \& Visperas, 1987). The higher number of spikelet and grains per panicle in 2011 was mainly due to lower number of panicles produced per unit area and distribution of photosynthate over fewer panicles in comparison to that of 2010. This is called dilution effect of photosysnthate distribution. Mengel and Kirkby (2001) observed that the distribution of available photosynthates was affected by both the number of panicles per unit area and number of spikelets per panicle. If the rate of assimilate production is limiting, a higher number of panicles per unit area is often accompanied by a reduction in the number of grains per panicle, and an increase in number of empty hulls (Mengel \& Kirkby, 2001). Our study suggested that increasing the number of panicles per unit area decreased the number of grains per panicle and reducing the grain number increased the grain size. This corroborates the findings of Dutta et al. (1998). The grain filling percentage and test weight increased by $8.6 \%$ and $7.4 \%$ respectively in 2010 over the year 2011. It has been observed that more number of grains and panicles per unit area ensured high percentage of grain filling (Gravois \& Helms, 1992). The cloudy weather and occasional rain during reproductive stage in 2011 might reduce grain filling percentage and test weight of rice in 2011 as compared to those of 2010 (Table 4). Higher rate on N application under RTNM showed a tendency of increasing panicle production and it increased up to medium SPAD value during both the years. FTNM also recorded higher panicle production comparable to those of the RTNM treatments but significantly superior to FFP and control plots. Grains per panicle showed an increasing tendency with higher amount of $\mathrm{N}$ application within RTNM in 2010; however, the same was not found in 2011. Grain-filling percentage was relatively stable in 2010, but in the next year highest filled grain was obtained at high SPAD value (SPAD 38) with high N rate $\left(35 \mathrm{~kg} \mathrm{ha}^{-1}\right)$ which was at par with medium SPAD value with all $\mathrm{N}$ rates. Test weight showed increasing tendency with high rate of N application among the RTNM treatments during both the years (Table 4). 
Table 4. Yield components of rice grown under different nitrogen management in Kharagpur, India

\begin{tabular}{|c|c|c|c|c|c|c|c|c|c|c|c|c|}
\hline Treatments & $\begin{array}{l}\mathrm{N} \\
\text { rate } \\
(\mathrm{kg} \\
\left.\mathrm{ha}^{-1}\right)\end{array}$ & $\begin{array}{l}\text { Panicles } \\
\mathrm{m}^{-2}\end{array}$ & $\begin{array}{l}\text { Grains } \\
\text { panicle }^{-1}\end{array}$ & $\begin{array}{l}\text { Grains } \\
\mathrm{m}^{-2}\end{array}$ & $\begin{array}{l}\% \\
\text { filled } \\
\text { grain }\end{array}$ & $\begin{array}{l}\text { Test } \\
\text { weight } \\
(\mathrm{g})\end{array}$ & $\begin{array}{l}\mathrm{N} \\
\text { rate } \\
(\mathrm{kg} \\
\left.\mathrm{ha}^{-1}\right)\end{array}$ & $\begin{array}{l}\text { Panicles } \\
\mathrm{m}^{-2}\end{array}$ & $\begin{array}{l}\text { Grains } \\
\text { panicle }^{-1}\end{array}$ & $\begin{array}{l}\text { Grains } \\
\mathrm{m}^{-2}\end{array}$ & $\begin{array}{l}\% \\
\text { filled } \\
\text { grain }\end{array}$ & $\begin{array}{l}\text { Test } \\
\text { weight } \\
\text { (g) }\end{array}$ \\
\hline & 2010 & & & & & & 2011 & & & & & \\
\hline $\mathrm{S}_{34} \mathrm{~N}_{15}$ & 55.0 & 321 & 63.4 & 20373 & 82.5 & 25.5 & 55.0 & 267 & 64.0 & 17137 & 70.8 & 23.1 \\
\hline $\mathrm{S}_{34} \mathrm{~N}_{25}$ & 63.3 & 339 & 64.4 & 21859 & 81.1 & 25.6 & 55.0 & 291 & 67.1 & 19518 & 72.1 & 24.0 \\
\hline $\mathrm{S}_{34} \mathrm{~N}_{35}$ & 76.7 & 355 & 66.1 & 23430 & 80.3 & 26.4 & 65.0 & 302 & 68.4 & 20727 & 71.6 & 24.8 \\
\hline $\mathrm{S}_{36} \mathrm{~N}_{15}$ & 70.0 & 346 & 64.2 & 22249 & 81.3 & 25.8 & 60.0 & 276 & 68.8 & 18983 & 71.6 & 23.7 \\
\hline $\mathrm{S}_{36} \mathrm{~N}_{25}$ & 80.0 & 358 & 65.5 & 23479 & 81.1 & 26.4 & 80.0 & 301 & 71.5 & 21517 & 73.4 & 24.4 \\
\hline $\mathrm{S}_{36} \mathrm{~N}_{35}$ & 88.3 & 378 & 67.2 & 25409 & 80.6 & 27.2 & 88.3 & 311 & 74.4 & 23120 & 74.5 & 25.0 \\
\hline $\mathrm{S}_{38} \mathrm{~N}_{15}$ & 85.0 & 351 & 65.1 & 22834 & 82.0 & 26.1 & 80.0 & 283 & 71.5 & 20277 & 73.9 & 24.4 \\
\hline $\mathrm{S}_{38} \mathrm{~N}_{25}$ & 96.7 & 361 & 66.5 & 24057 & 80.9 & 26.9 & 96.7 & 309 & 78.6 & 24298 & 74.6 & 24.9 \\
\hline $\mathrm{S}_{38} \mathrm{~N}_{35}$ & 111.7 & 367 & 65.4 & 24013 & 78.7 & 27.6 & 100.0 & 312 & 81.4 & 25355 & 80.9 & 25.3 \\
\hline FTNM & 120.0 & 358 & 63.2 & 22634 & 79.8 & 26.9 & 120.0 & 306 & 75.3 & 22947 & 73.7 & 25.0 \\
\hline FFP & 60.0 & 285 & 59.3 & 16915 & 79.8 & 25.6 & 60.0 & 243 & 66.7 & 16219 & 77.5 & 24.5 \\
\hline Control & 0.0 & 253 & 47.0 & 11805 & 80.9 & 24.4 & 0.0 & 207 & 56.0 & 11576 & 76.8 & 23.5 \\
\hline Mean & & 339 & 63.1 & 21588 & 80.7 & 26.2 & & 284 & 70.3 & 20140 & 74.3 & 24.4 \\
\hline $\operatorname{LSD}(0.05)$ & & 40 & 6.1 & 3603 & 3.3 & 1.8 & & 25 & 8.2 & 3032 & 7.1 & 1.5 \\
\hline
\end{tabular}

The subscripts of S represent the SPAD threshold value and the subscripts of $\mathrm{N}$ represent the amount top dressed as $\mathrm{kg} \mathrm{N} \mathrm{ha}^{-1}$ in each application; FTNM - Fixed Time Nitrogen Management; FFP - Farmers' Fertilizer Practice.

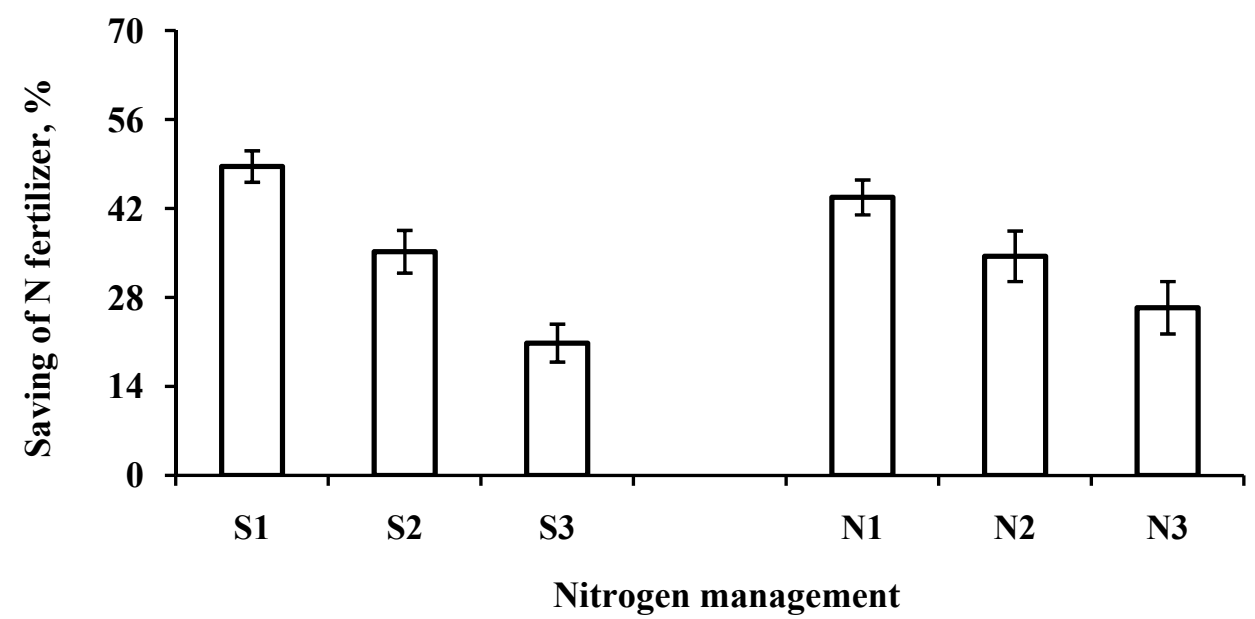

S1, S2 and S3 represent SPAD threshold levels of 34, 36 and 38 respectively; N1, N2 and N3 represent $\mathrm{N}$ top dressing at 15, 25 and 35 $\mathrm{kg}$ ha-1, in repectively.

Figure 6. Saving of $\mathrm{N}$ fertilizer use under SPAD based real time $\mathrm{N}$ management over fixed time $\mathrm{N}$ management (averaged over two years). The vertical lines indicate the standard error 


\section{Conclusion}

SPAD meter is a reliable tool which is used to determine the right time for $\mathrm{N}$ topdressing and identify $\mathrm{N}$ levels for more precise $\mathrm{N}$ management in rice. The benefit was largely associated with timing of fertilizer $\mathrm{N}$ top dressing according to the need of the crop. The results showed that SPAD meter based N application in RTNM produced rice yields similar to that of existing fertilizer recommendation in FTNM; but, SPAD meter based N management saved 27 to $54 \%$ fertilizer N in comparison to FTNM. Especially maintaining SPAD threshold 36, application of 35 and $25 \mathrm{~kg} \mathrm{~N}^{-1}$ could save the fertilizer $\mathrm{N}$ by 20 to $35 \%$ as compared to FTNM with a marginal positive impact on grain yield (Figure 6). The SPAD value of 36 was found to be critical for Eastern India, unlike the value of 35 recommended for the Philippines. Our study showed that application of less amount of fertilizer $\mathrm{N}$ in split during tillering to heading stage under RTNM improved the growth and productivity of rice as compared to those in FTNM. The results suggest revising the timing of fertilizer N application in FTNM. Application of 55 to $88 \mathrm{~kg} \mathrm{~N} \mathrm{ha}^{-1}$ in two to three splits during tillering to flowering as per need of the crop led to better $\mathrm{N}$ use efficiency. RTNM was found to be more effective in producing high grain yield with greater $\mathrm{N}$ use efficiency of 'IR 36' as compared to FTNM. Further increase in grain yield are likely to occur if needful steps are taken in fine tuning of soil fertility and crop management. The SPAD based precision N management concept has been demonstrated promising agronomic potential with increased rice yield and $\mathrm{N}$ use efficiency. Acknowledgement

National Agricultural Innovation Project of Indian Council of Agricultural Research, New Delhi is gratefully acknowledged for funding the research programme.

\section{References}

Balasubramanian, V., Morales, A. C., Cruz, R. T. \& Abdulrachman, S. (1999). Onfarm adaptation of knowledge-intensive nitrogen management technologies for rice systems. Nutr. Cycl. Agroecosyst, 53, 59-69. http://dx.doi.org/10.1023/A:1009744605920

Balasubramanian, V., Morales, A. C., Thiyagarajan, T. M., Nagarajan, R., Babu, M., Abdulrachman, S., \& Hai, L. H. (2000). Adoption of the chlorophyll meter (SPAD) technology for real-time N management in rice: a review. Int. Rice Res. Newsletter, 25, 4-8.

Cassman, K. G., Peng, S., Olk, D. C., Ladha, J. K., Reichardt, W., Dobermann, A., \& Singh, U. (1998). Opportunities for increased nitrogen use efficiency from improved resource management in irrigated rice systems. Field Crops Research, 56, 7-38. http://dx.doi.org/10.1016/S0378-4290(97)00140-8

Dutta, R. K., Baset, Mia, M. A., Lahiri, B. P., \& Salam, M. A. (1998). Assessment of grain yield and quality improvements in rice by modern breeding techniques in Bangladesh and projections of future rice improvements. International Rice Commission Newsletter. (FAO), 46, 63-70.

Dobermann, A., \& White, P. F. (1998). Strategies for nutrient management in irrigated and rainfed lowland rice systems. Nutr. Cycl. Agroecosyst, 53, 1-18. http://dx.doi.org/10.1023/A:1009795032575

Dobermann, A., Witt, C., Dawe, D., Gines, H. C., Nagarajan, R., Satawathananont, S., ... Adviento, M. A. A. (2002). Site-specific nutrient management for intensive rice cropping systems in Asia. Field Crops Research, 74, 37-66. http://dx.doi.org/10.1016/S0378-4290(01)00197-6

Gholizadeh, A., Amin, M. S. M., Anuar, A. R., Aimrun, W., \& Saberioon, M. M. (2011). Temporal Variability of SPAD chlorophyll meter readings and its relationship to total nitrogen in leaves within a Malaysian paddy field. Australian Journal of Basic and Applied Sciences, 5(5), 236-245.

Gravois, K. A., \& Helms, R. S. (1992). Path analysis of rice yield and yield components as affected by seeding rate. Agronomy Journal, 84, 1-4. http://dx.doi.org/10.2134/agronj1992.00021962008400010001x

Huang, J., He, F., Cui, K., Roland, J., Buresh, B. X., Gong, W., \& Peng, S. (2008). Determination of optimal nitrogen rate for rice varieties using a chlorophyll meter. Field Crops Research, 105, 70-80. http://dx.doi.org/10.1016/j.fcr.2007.07.006

Hussain, F., Bronson, K. F., Yadvinder, S., Bijay, S., \& Peng, S. (2000). Use of chlorophyll meter sufficiency indices for nitrogen management of irrigated rice in Asia. Agron. J., 92, 875-879.

Mengel, K., \& Kirkby, E. A. (2001). Principles of plant nutrition, Springer book.

Peng, S., Buresh, R. J., Huang, J., Yang, J., Zou, Y., Zhong, X., Wang, G., \& Zhang, F. (2006). Strategies for overcoming low agronomic nitrogen use efficiency in irrigated rice systems in China. Field Crops Research, 96, 37-47. http://dx.doi.org/10.1016/j.fcr.2005.05.004 
Peng, S., Garcia, F. V., Laza, R. C., \& Cassman, K. G. (1993). Adjustment for specific leaf weight improves chlorophyll meter's estimate of rice leaf nitrogen concentration. Agronomy. Journal, 85, 987-990. http://dx.doi.org/10.1016/0378-4290(96)00018-4

Peng, S., Garcia, F. V., Laza, R. C., Sanico, A. L., Visperas, R. M., \& Cassman, K. G. (1996). Increased N-use efficiency using a chlorophyll meter on high yielding irrigated rice. Field Crops Research, 47, $243-252$. http://dx.doi.org/10.2134/agronj1993.00021962008500050005x

Singh, B., Singh, Y., Ladha, J. K., Bronson, K. F., Balasubramanian, V., Singh, J., \& Khind, C. S. (2002). Chlorophyll meter- and leaf color chart-based nitrogen management for rice and wheat in northwestern India. Agronomy Journal, 94, 821-829. http://dx.doi.org/10.2134/agronj2002.0821

Singh, B., Singh, V., Singh, Y., Thind, H. S., Kumar, A., Gupta, R. K., Kaul, A. \& Vashistha, M. (2012). Fixed-time adjustable dose site-specific fertilizer nitrogen management in transplanted irrigated rice (Oryza sativa L.) in South Asia. Field Crops Research, 126, 63-69. http://dx.doi.org/10.1016/j.fcr.2011.09.007

Takabe, M. \& Yoneyama, T. (1989). Measurement of leaf color scores and its implication to nitrogen nutrition of rice plants. Japan Agriculture Research, 23, 86-93.

Tirol-Padre, A., Ladha, J. K., Singh, U., Laureles, E., Punzalan, A., \& Akita, S. (1996). Grain yield performance of rice genotypes at suboptimal levels of soil $\mathrm{N}$ as affected by $\mathrm{N}$ uptake and utilization efficiency. Field Crops Research, 46, 127-143. http://dx.doi.org/10.1016/0378-4290(95)00095-X

Venkateswarlu, B., \& Visperas, R. M. (1987). Source-sink relationships in crop plants. International Rice Research Institute (IRRI) research paper $\quad$ series. $\quad$ Number 125. http://www.scribd.com/doc/74345410/IRPS-125-Source-sink-relationships-in-crop-plants.

Virmani, S. S. (1996). Hybrid rice. Advances in Agronomy, 57, $377-462$. http://dx.doi.org/10.1016/S0065-2113(08)60928-1

Watson, D. J. (1952). The physiological basis of variation in yield. Advances in Agronomy, 4, 101-145. http://dx.doi.org/10.1016/S0065-2113(08)60307-7 